\title{
Piglets produced by transfer of embryos obtained by in vitro fertilization of oocytes matured in vitro with thymosin: A case report ${ }^{11}$
}

\author{
KATARZYNA PONIEDZIAŁEK-KEMPNY, BARBARA GAJDA, \\ IWONA RAJSKA, LECHOSŁAW GAJDA, ZDZISŁAW SMORĄG \\ Department of Reproductive Biotechnology and Cryopreservation, \\ National Research Institute of Animal Production, 32-083 Balice/Kraków, Poland
}

Poniedziałek-Kempny K., Gajda B., Rajska I., Gajda L., Smorąg Z. Piglets produced by transfer of embryos obtained by in vitro fertilization of oocytes matured in vitro with thymosin: A case report

Summary

The aim of the study was to examine the in vivo viability of in vitro-produced (IVP) porcine embryos obtained from oocytes matured with thymosin. The research material for this study consisted of immature pig oocytes obtained from ovaries after slaughter and ejaculated semen obtained from one boar. The immature oocytes were cultured in vitro until the metaphase II stage in a medium supplemented with thymosin (TMS). The presumptive zygotes obtained were cultured in vitro for 4-40 hours. The presumptive zygotes and 2-4-cell embryos were evaluated in vivo after transferring them to synchronized recipients. After the transfer of embryos from the experimental group into 2 recipients (50 embryos into each gilt) and the transfer of 50 embryos from the control group into 1 recipient, both gilts that had received embryos obtained by in vitro fertilization of oocytes matured with TMS became pregnant and delivered a total of 16 live piglets. After the transfer of embryos from the control group, no pregnancy was achieved. In conclusion, the results of our preliminary study suggest that the maturation of pig oocytes with thymosin supports the in vivo survival of in vitro produced embryos. It is important to note, that this was the first birth of piglets obtained after transfer of IVP embryos in Poland.

Keywords: pig, oocyte maturation, thymosin, embryo transfer

Research in the field of in vitro production of porcine embryos started over 30 years ago, and in 1986 first piglets were born from in vivo-matured oocytes (5). However, the first piglets from embryos obtained by the complex in vitro method, i.e. oocyte maturation, fertilization, and culture without the female organism, were born in 1993 (31). The constant development of biotechnological and biomedical studies on pigs indicates that there is a steady increase in demand for matured porcine oocytes and embryos. Associated reproductive techniques (ART) and embryo transfer (ET) in pigs are beneficial not only for improving the rate of genetic progress without the risk of disease transmission and the costs of live animal transfer, but also for other reproductive biotechnologies (35). These techniques are dependent on porcine in vitro production (IVP), which includes in vitro maturation (IVM),

Supported by the Fund for Research at IZ PIB, project no. 07-2.06.7 (part of a doctoral dissertation) and BIOSTRATEG2/297267/14/NCBR/2016. in vitro fertilization (IVF), and the subsequent in vitro culture (IVC). Important issues related with embryo IVP are the quality of in vitro-matured oocytes, the quality of semen intended for IVF, polyspermy, and the quality of in vitro-obtained embryos. Many laboratories have been trying to improve IVP procedures, but despite visible progress, the effectiveness and repetitiveness of the IVP method, especially in pigs, is still unsatisfactory. The maturation of pig oocytes is one of the most important stages in the embryo IVP process. In vitro oocyte maturation requires an appropriate environment that is as close to in vivo conditions as possible. These conditions can be achieved by various in vitro culture systems based on media with a strictly defined chemical composition. Methods for in vitro maturation of pig oocytes have been significantly improved in recent years, resulting in about 50-90\% of oocytes reaching nucleus maturity, i.e. the metaphase II stadium $(14,20,36,37)$. Oocyte maturation 
media are modified by a variety of supplements, such as hormones: FSH, hCG, eCG (33), fetal calf serum (FCS) (1), porcine follicular fluid (pFF) (21), growth factors (36), and hyaluronic acid (27). Currently in use are also antioxidants: resveratrol (15), phycocyanin (16), and chlorogenic acid (20). In our previous study, we demonstrated that maturation of pig oocytes in a medium supplemented with thymosin increased the number of matured oocytes and improved the quality of in vitro-obtained pig blastocysts (11). Thymosin (TMS) is a peptide hormone that consists of 28 amino acids. It plays a major role in skeletal muscle regeneration (13) and supports the regeneration of cardiac muscles as well $(3,13)$. Little is known about the expression of the thymosin family and its functions in the ovary, especially in domestic animals (26). It has been suggested that $\alpha$ - and $\beta$-thymosins can modulate gonadotrophin-induced steroidogenesis in rat granulosa cells. Therefore, thymosin can have an effect on ovarian functions (26). According to other findings, concentrations of $\alpha$ - and $\beta$-thymosins in bovine and porcine blood change throughout the oestrus cycle (7). Until now functions of thymosin have been examined only in bovine oocytes (28).

The in vitro culture conditions are an important factor that influences the quality and number of in vitro-obtained embryos. The most commonly used media for pig embryo culture are North State Carolina University (NCSU-23 or NCSU-37) $(22,23)$, modified Whitten medium (mWM) (2), Beltsville Embryo Culture Medium 3 (BECM-3) (6), and Porcine Zygote Medium, (PZM) (32). Modifications of these culture media for pig embryos obtained in vitro lead to increased numbers of developing embryos, but the ratio of blastocysts obtained remains unsatisfactory and does not exceed $50 \%(12,18,37)$.

The aim of this study was to examine the in vivo viability of IVP porcine embryos obtained from oocytes matured with thymosin.

\section{Material and methods}

All experimental procedures were approved by the $2^{\text {nd }}$ Local Ethics Committee in Kraków (1181/2015, May 21, 2015).

Ovaries were obtained from a local slaughterhouse, transported to the laboratory within $2 \mathrm{~h}$, and washed three times in phosphate buffered saline (PBS) with addition of $2 \%$ kanamycin at a temperature of $39^{\circ} \mathrm{C}$. Oocytes were obtained by two methods: by aspiration from antral follicles 3 to $6 \mathrm{~mm}$ in diameter and by cutting the follicle in the ovaries with a surgical blade. Cumulus-oocyte complexes (COCs) with several layers of compact cumulus cells surrounding the oocyte were aspirated and washed several times in TCM-199 Hepes (Tissue Culture Medium 199 Hepes) supplemented with $10 \%$ fetal calf serum (FCS) and 0.068 $\mathrm{mg} / \mathrm{ml} \mathrm{kanamycin}$, at $39^{\circ} \mathrm{C}$, adjusted to $\mathrm{pH} 7 \cdot 0-7.2$. Oocytes with homogeneous ooplasm and with multilayered compact cumulus mass were selected for maturation. COCs were matured in a modified TCM-199 medium (17). This medium consisted of TCM-199 supplemented with $1.0 \mathrm{mM}$ cysteine, $10 \% \mathrm{FCS}, 10 \%$ porcine follicular fluid, $1 \mathrm{mM}$ dibutryl cAMP (dbcAMP), $10 \mathrm{IU} / \mathrm{ml}$ equine chorionic gonadotrophin (eCG), and $10 \mathrm{IU} / \mathrm{ml}$ human chorionic gonadotrophin (hCG). In the first $22 \mathrm{~h}, \mathrm{COCs}$ were cultured in this medium, then oocytes were matured for the next $22 \mathrm{~h}$ in the same medium, but without hormones and dbcAMP. All cultures were carried out in groups of 10-12 oocytes in $100 \mu$ of the medium under mineral oil in a humidified atmosphere containing $5 \% \mathrm{CO}_{2}$ in the air, at $39^{\circ} \mathrm{C}$, (incubator, Sanyo). In the experimental group, oocytes were matured with $1 \mathrm{mg} / 1 \mathrm{ml}$ of TMS, whereas in the control group, they were matured without this supplement. After the maturation period, COCs were assessed morphologically, as well as the cumulus expansion and ooplasm morphology were estimated. The presence of the first polar body was evidence of reaching the MII stage. Matured oocytes from the experimental and control groups were fertilized with ejaculated boar semen. Ejaculated semen was obtained from one boar and diluted with a commercial extender. The motility and concentration of sperm were evaluated. Semen was capacitated in vitro in a modified mM-199 medium (17, 30) that consisted of TCM-199 supplemented with 2.92 $\mathrm{mM} \mathrm{CaCl}, 0.91 \mathrm{mM}$ sodium pyruvate, $3.05 \mathrm{mM}$ glucose, $25 \mathrm{mM}$ Hepes, and $10 \%$ BSA. A portion of $1 \mathrm{ml}$ of ejaculated semen was centrifuged at $6000 \mathrm{rpm}$ for $25 \mathrm{~s}$. Then, the sperm pellet was washed twice by centrifuging in PBS with $0.001 \mathrm{~g} / \mathrm{ml} \mathrm{BSA}$. After washing, $1 \mathrm{ml}$ of capacitation medium was added to the sperm pellet and then centrifuged once again at $6000 \mathrm{rpm}$ for $25 \mathrm{~s}$. The final sperm concentration was adjusted in the capacitation medium to $1 \times 10^{5} / \mathrm{ml}$ and pre-incubated for $1 \mathrm{~h}$ at $39^{\circ} \mathrm{C}$. For in vitro fertilization, a portion of $50 \mu \mathrm{l}$ of sperm was added to a group of 10-12 oocytes placed in a $50 \mu 1$ droplet of fertilization medium that consisted of the same supplements as mM-199, but with addition $10 \mathrm{mM}$ caffeine. Gametes were co-incubated for $4 \mathrm{~h}$ in a humidified atmosphere containing $5 \% \mathrm{CO}_{2}$ in the air at $39^{\circ} \mathrm{C}$, (incubator, Sanyo). Inseminated oocytes were removed from droplets and washed four times in NCSU-23 (IVC) medium. After washing, presumed zygotes were transferred into a 4-well plastic dish (Nunc) with IVC medium and were cultured at $39^{\circ} \mathrm{C}$ in a humidified atmosphere of $5 \% \mathrm{CO}_{2}, 5 \% \mathrm{O}_{2}$ and $90 \% \mathrm{~N}_{2}$ from 4 to $40 \mathrm{~h}$. Development to 2-cell and 4-cell embryos was assessed 1 and 2 days after IVF. To evaluate the in vitro and in vivo embryonic development, embryos were transferred into two gilts from the experimental group (+TMS) and one from the control group (-TMS). The embryo recipients were 6 -month-old gilts weighing $90 \mathrm{~kg}$. The gilts were synchronized intramuscularly with 750 i.m. of PMSG (Folligon, Intervet, Holland). After $72 \mathrm{~h}$, the recipients were given 500 i.m. of HCG (Chorulon, Intervet, Holland) and the signs of oestrus were monitored for the next $24 \mathrm{~h}$. The transfer of embryos was carried out surgically by making an incision in the linea alba in order to perform laparotomy. Before transfer, the recipients were prepared for general anesthesia by premedication with azaperone (Stresnil, Elanco Animal Health) intramuscularly ( $1 \mathrm{ml} / 10 \mathrm{~kg}$ of weight) and with ketamine (Ketamina, Biowet, Puławy) and xylazine (Sedazin, 
Biowet, Puławy) intravenously (both $10 \mathrm{mg} / 10 \mathrm{~kg}$ of weight). Transfer took place on the first or second day after the oestrus synchronization (the day of oestrus was defined as day 0). Presumptive zygotes and 2-4-cell stage embryos selected for transfer were evaluated under a stereoscopic microscope. Next, these embryos were placed with PBS+ $10 \%$ FCS solution (about $10 \mu \mathrm{m}$ ) in a special polyurethane tube by means of a Hamilton ${ }^{\circledR}$ syringe ( $50 \mu \mathrm{m}$ in volume). The tube with embryos was inserted into the oviduct through the imfundibulum. Each recipient received 50 presumptive zygotes or 2-4-cell stage embryos. The effectiveness of the transfer was evaluated on the basis of a diagnosis of the recepients at days 30 and 45 after the embryo transfer with an ultrasonograph (Dramiński, Poland) and on the basis of the number of piglets born. The pregnant recipients were monitored until parturition, and the total number of piglets born in particular litters was determined (24) Statistical analysis was performed by the SAS version 9.3. Data were analyzed by the $\mathrm{Chi}^{2}$ test.

\section{Results and discussion}

One hundred and forty-seven oocytes were selected for maturation in an IVM medium supplemented with thymosin $(1 \mathrm{mg} / 1 \mathrm{ml})$ (experimental groups). The percentage of matured oocytes in the experimental groups was higher than it was in the control group $(80.3 \%$ and
$77.5 \%$ respectively), but there were no statistically significant differences. After maturation, one hundred and eighteen oocytes in metaphase II were fertilized. The fertilized oocytes were cultured in vitro for 4-40 h. Eighty-two presumptive zygotes and eighteen 2-4-cell stage embryos were transferred to two synchronized recipients (50 presumptive zygotes and 2-4-cell stage embryos per recipient) (Fig. 1, Tab. 1).

In the control group (-TMS), eighty oocytes were selected for maturation in an IVM medium without the addition of thymosin. After maturation, sixty-two oocytes in metaphase II were fertilized. The fertilized oocytes were cultured in vitro for $40 \mathrm{~h}$. Forty-five presumptive zygotes and five 2-4-cell cell stage embryos were transferred to one synchronized recipient (Fig. 2, Tab. 2).

Thirty days after the transfer, the two recipients that had received 50 embryos each, obtained by in vitro fertilization of oocytes matured with the addition of thymosin (experimental group), were found to be pregnant. The next examination, 45 days after embryo transfer, confirmed both pregnancies. Six live piglets were born from one recipient and 10 from the other (Tab. 2). The pregnancy effectiveness in our experimental group was $100 \%$, whereas the effectiveness of

Tab. 1. In vitro evaluation of the viability of embryos obtained by IVF of porcine oocytes matured with thymosin

\begin{tabular}{|c|c|c|c|c|c|}
\hline \multirow[b]{2}{*}{ Group } & \multicolumn{5}{|c|}{ Number of } \\
\hline & $\begin{array}{l}\text { Oocytes selected for } \\
\text { maturation }\end{array}$ & Fertilized oocytes (\%) & Presumptive zygotes & 2-4-cell stage embryos & $\begin{array}{l}\text { Presumptive zygotes \& } \\
\text { embryos selected for TPT }\end{array}$ \\
\hline Experimental (+TMS) & 147 & $118(80.3)$ & 82 & 18 & 100 \\
\hline Control (-TMS) & 80 & $62(77.5)$ & 47 & 5 & 50 \\
\hline
\end{tabular}

Tab. 2. Results of the transfer of embryos obtained by in vitro fertilization of oocytes matured with thymosin

\begin{tabular}{|l|c|c|c|c|c|}
\hline \multicolumn{1}{|c|}{ Group } & Recipients & $\begin{array}{c}\text { Embryos transferred to } \\
1 \text { recipient }\end{array}$ & Stage of embryos & $\begin{array}{c}\text { Pregnant recipients } \\
(\%)\end{array}$ & Piglets born alive (\%) \\
\hline Experimental (+TMS) & 2 & 50 & Presumptive zygotes & 2 (100) & $16(16)$ \\
Control (-TMS) & 1 & 50 & and 2-4b & 0 & - \\
\hline
\end{tabular}

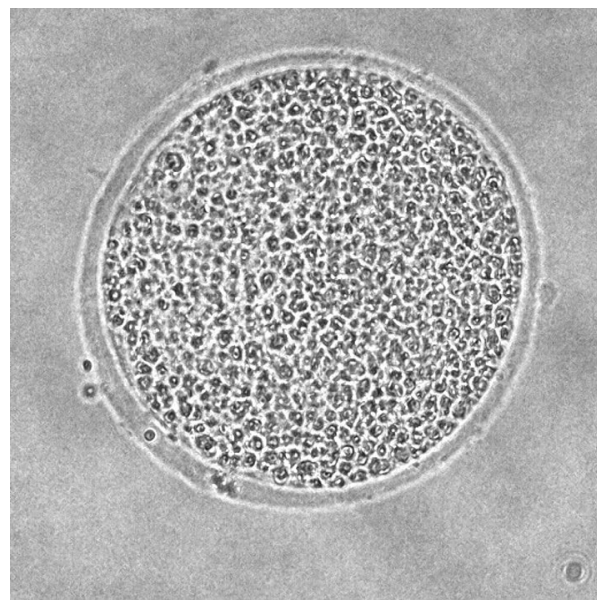

Fig. 1. Pig oocyte (MII) obtained after in vitro maturation with thymosin
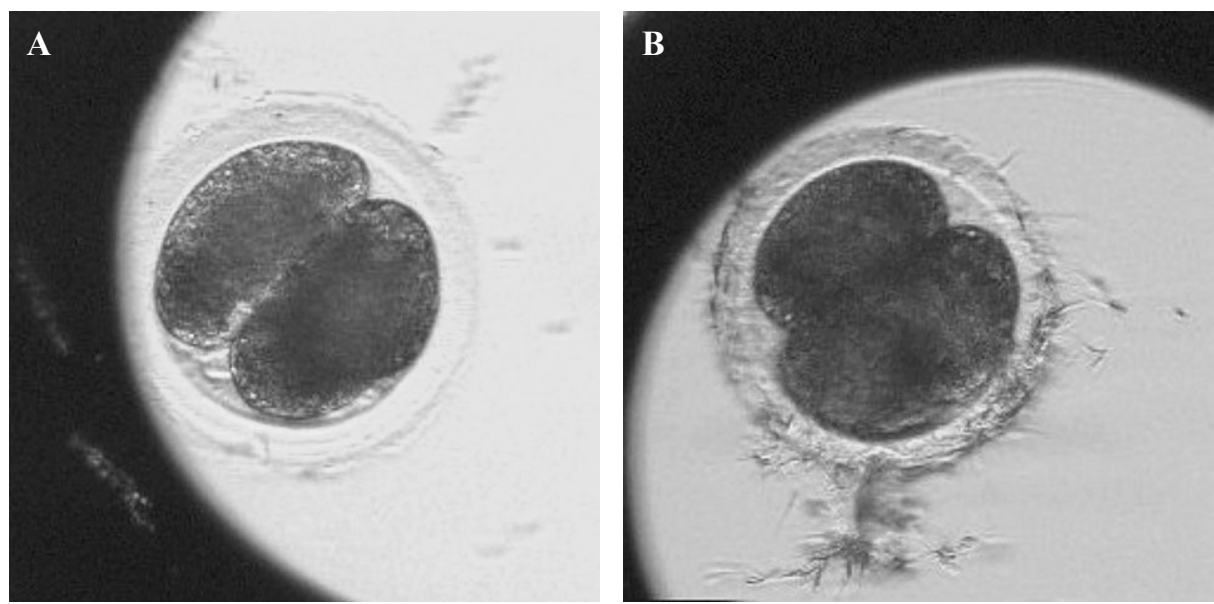

Fig. 2. Porcine 2-cell (A) and 3-4-cell stage embryos (B) obtained after fertilization of oocytes matured with thymosin selected for embryo transfer (Time-Lapse, PrimoVision ${ }^{\circledR}$ ) 


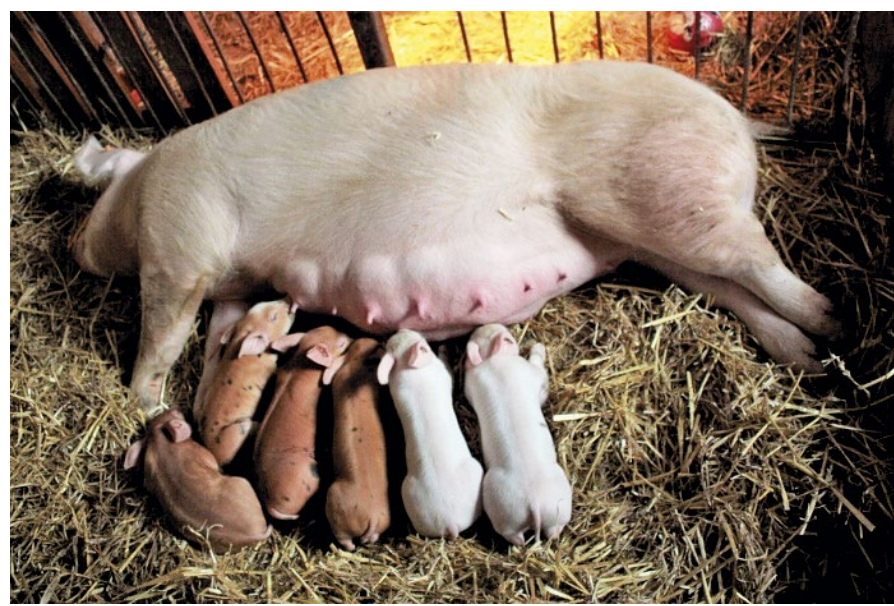

Fig. 3. Piglets born after the transfer of embryos obtained by in vitro fertilization of oocytes matured with thymosin

piglet production was $16 \%$. Both deliveries occurred at term. In the recipient from the control group (-TMS) no pregnancy was found (at days 30 and 45) (Fig. 3).

The transfer of porcine embryos in breeding is limited by the difficulty of collecting pig embryos by surgical or non-surgical techniques, which results from the anatomical complexity of the cervix and uterus. Porcine ET is essential for biotechnological techniques, especially for conducting genetic improvements and maintaining superior genotypes. Pig ET can also support the controlling mechanisms of animal reproduction (29). Usually, embryos are transferred surgically into recipients. Depending on the stage of development, embryos, are transferred either into the oviduct (one- to four-cell embryos) or into the tip of the uterine horn (8-cell embryos to blastocyst). Nonsurgical procedures are an alternative to the surgical method. These methods are used to eliminate surgical intervention and the narcosis associated with it. Endoscopic and laparoscopic techniques are employed in the minimally invasive procedures, whereas in nonsurgical procedures, embryos are transferred through the cervix without surgery (10). The surgical method, however, is still the most commonly used technique during experiments because its effectiveness is higher $(70 \%)$ than that of the non-surgical methods $(56 \%)$ (4). The success of embryo transfer depends on various factors. One of the most important is the quality of matured oocytes selected for in vitro fertilization. Porcine oocytes cultured in vitro have lower developmental competence than those that develop in vivo, which is shown by a lower percentage of cleavage, morulae and blastocysts $(18,19,25)$. In view of the fact that thymosin appears to positively affect oocyte maturation (9), we decided to evaluate the in vivo survivability of embryos produced by in vitro fertilization of oocytes matured with the addition of thymosin. To achieve the best possible effectiveness of ET, two factors were taken into consideration: the stage of the embryos transferred and their number. In our experiment, we decided to transfer presumptive zygotes and 2-4-cell stage embryos after culturing them for $4-40 \mathrm{~h}$ from IVF, because of reports that the oviductal condition might support embryonic development (19) and because of the well-known occurrence of the "four-cell block" in pig embryo development. We transferred 50 embryos into each recipient. Some reports suggest that the transfer of 16-20 embryos may be optimal to achieve normal pregnancy rates, but Fowler et al. (8) mention using over 30 embryos to increase the likelihood of pregnancy. In our experiment, the transfer of embryos obtained from fertilized oocytes cultured with thymosin resulted in pregnancies in both recipients and the subsequent birth of 16 live piglets. Pregnancy did not occur in the recipient from the control group. The percentage of pregnancy obtained $(100 \%)$ was higher than the results of Yuan et al. (36) (53\%). The effectiveness of obtaining piglets (calculated as the ratio of the number of piglets to the number of embryos transferred to the recipients) was lower (10\%) in experiments by Nakamura et al. (19), but higher $(26 \%)$ in those by Yoshioka (34). Researchers report widely varying pregnancy effectiveness figures, from $17 \%$ with 2.4 piglets to $100 \%$ with 10.8 piglets (4). Although the effectiveness of IVP embryo transfer in our experiment was low, it was the first time that piglets were obtained by this method in Poland.

In conclusion, our preliminary study suggests that the maturation of pig oocytes with thymosin supports the in vivo survival of IVP embryos. This study permitted us to set up IVP embryo transfer successfully, but further experiments on a larger number of animals are needed to validate the results of this study.

\section{References}

1. Batista R. I., Moro L. N., Corbin E., Alminana C., Gonçalves Souza-Fabian J. M., de Figueirêdo Freitas V.J., Mermillod P.: Combination of oviduct fluid and heparin to improve monospermic zygotes production during porcine in vitro fertilization. Theriogenology 2016, 86, 495-502.

2. Beckmann L. S., Day B. N.: Effects of media $\mathrm{NaCl}$ concentration and osmolarity on the culture of early-stage porcine embryos and the viability of embryos cultured in a selected superior medium. Theriogenology 1993, 39, 611-622.

3. Bock-Marquette I., Saxena A., White M. D., DiMaio J. M., Srivastava D. Thymosin $\beta 4$ activates integrin-linked kinase and promotes cardiac cell migration, survival and cardiac repair. Nature 2004, 432, 7016, 466-472.

4. Brüssow K. P., Rátky J., Antosik P., Kempisty B., Jaśkowski J. M.: An indispensable key for the application of reproductive technique. EJPAU 2018, 21, $1-6$.

5. Cheng W. T. K., Polge C., Moor R. M.: In vitro fertilization of pig and sheep oocytes. Theriogenology 1986, 25, 146 (abstract).

6. Dobrinsky J. R., Johnson L. A., Rath D.: Development of a culture medium (BECM-3) for porcine embryos: effects of bovine serum albumin and fetal bovine serum on embryo development. Biol. Reprod. 1996, 55, 1069-1074.

7. Ford J. J., Vakharia D. D., Anderson L. L., Klindt J.: Thymosin-beta 4 concentrations during the estrous cycle and after hypophyseal stalk transection of female pigs. Proc. Soc. Exp. Biol. Med. 1990, 193, 185-189.

8. Fowler K. E., Mandawala A. A., Griffin D. K., Walling G. A., Harvey S. C.: The production of pig preimplantation embryos in vitro: Current progress and future prospects. Reprod. Biol. 2018, 18, 203-211.

9. Gajda B., Poniedziałek-Kempny K., Rajska I., Smorag Z.: Effect of thymosin on in vitro fertilization and developmental competence and quality of pig embryos. Proc. $31^{\text {st }}$ Meeting AETE, Ghent, Belgium, Animal. Reprod. 2015, 12,735

10. Gajda B., Poniedziałek-Kempny K., Rajska I., Smorag Z.: Wpływ tymozyny na dojrzewanie in vitro oocytów świni. Proc. LXXIX Zjazd Naukowy PTZ, Siedlce 15-17 września 2014, p. 125. 
11. Gajda B., Smorag Z.: Kriokonserwacja oocytów i zarodków świni - aspekty biologiczne i biotechnologiczne. Ośrodek Wydawnictw Naukowych, Poznań 2013, p. 130

12. Gil M. A., Nohalez A., Martinez C. A., Ake-Villanueva J. R., CenturionCastro F., Maside C., Cuello C., Roca J., Parrilla I., Martinez E. A.: Effects of meiotic inhibitors and gonadotrophins on porcine oocytes in vitro maturation, fertilization and development. Reprod. Domest. Anim. 2017, 52, 873-880.

13. Hara T.: Thymosins and muscle regeneration. Vitam. Horm. 2011, 87, 277-286.

14. Lee S., Jin J. X., Khoirinaya C., Kim G. A., Lee B. C.: Lanosterol influences cytoplasmic maturation of pig oocytes in vitro and improves preimplantation development of cloned embryos. Theriogenology 2016, 85, 575-584.

15. Lee S., Jin J. X., Taweechaipaisankul A., Kim G. A., Lee B. Ch.: Synergistic effect of resveratrol and melatonin on in vitro maturation of porcine oocytes and subsequent embryo development. Theriogenology 2018, 114, 191-198.

16.Liang S., Guo J., Jin Y. X., Yuan B., Zhang J. B., Kim N. H.: C-Phycocyanin supplementation during in vitro maturation enhances pre-implantation developmental competence of parthenogenetic and cloned embryos in pigs. Theriogenology 2018, 106, 69-78.

17. Mandryk $I$.: Optymalizacja warunków hodowli zarodków uzyskanych po zapłodnieniu metodą ICSI świeżych i kriokonserwowanych oocytów świni. Doct. diss. Instytut Zootechniki, Balice 2013.

18. Nagai T., Yamauchi N., Kikuchi K.: Nuclear and cytoplasmic maturation in vitro of porcine oocytes. J. Reprod. Dev. 2001, 47, S55-S62.

19. Nakamura Y., Tajima S., Kikuchi K.: The quality after culture in vitro or in vivo of porcine oocytes matured and fertilized in vitro and their ability to develop to term. Anim. Sci. J. 2017, 88, 1916-1924.

20.Nguyen T. V., Tanihara F., Do L., Sato Y., Taniguchi M., Takagi M., Van Nguyen T., Otoi T.: Chlorogenic acid supplementation during in vitro maturation improves maturation, fertilization and developmental competence of porcine oocytes. Reprod. Domest. Anim. 2017, 52, 969-975.

21. Oberlender G., Murgas L. D. S., Zangeronimo M. G., Silva A. C., Menezes T. D. A., Pontelo T. P., Vieira L. A.: Role of insulin-like growth factor-I and follicular fluid from ovarian follicles with different diameters on porcine oocyte maturation and fertilization in vitro. Theriogenology 2013, 80, 4, 319-327.

22. Petters $R$. M.: In vitro culture of early stage embryos from livestock. Tiss Cult. Res. Comm. 1992, 11, 305-313.

23. Petters R. M., Wells K. D.: Culture of pig embryos. J. Reprod. Fertil. 1993, 48, 61-73.

24. Poniedziałek-Kempny K.: Wpływ zmodyfikowanych warunków dojrzewania oocytów oraz jakości i sposobu przygotowania nasienia knura na pozaustrojowe zapłodnienie u świni. Doct. diss. Instytut Zootechniki, Balice 2019.

25. Romek M., Gajda B., Krzysztofowicz E., Kucia M., Uzarowska A., Smorag Z. Improved quality of porcine embryos cultured with hyaluronan due to the modification of the mitochondrial membrane potential and reactive oxygen species level. Theriogenology 2017, 102, 1-9.

26. Salhab M., Papillier P., Perreau Ch., Guyader-Joly C., Dupont J., Mermillod P. Uzbekova S.: Thymosins $\beta-4$ and $\beta-10$ are expressed in bovine ovarian follicles and upregulated in cumulus cells during meiotic maturation. Reprod. Fertil. Dev. 2010, 22, 1206-1221.

27. Sato E., Miyamoto H., Koide S.: Glycoaminoglycans in porcine follicular fluid promoting viability of oocytes in culture. Mol. Reprod. Dev. 1990, 26, 391-397.

28. Skowronek O., Zdebska N., Opiela J.: The impact of thymosin $\beta 4$ on bovine oocytes meiotic maturation and fragmentation DNA. Proc. $4^{\text {th }}$ Winter Workshop of the Society for Biology of Reproduction. Zakopane, 3-5 February 2016 , p. 25.

29. Suzuki Ch., Iwamura Sh., Yoshioka K.: Birth of piglets through the non-surgical transfer of blastocysts produced in vitro. J. Reprod. Dev. 2004, 50, 487-491.

30. Yang J. G., Chen W. Y., Li P. S.: Effects of glucocorticoids on maturation of pig oocytes and their subsequent fertilizing capacity in vitro. Biol. Reprod. 1999, 70, 159-169.

31. Yoshida M., Mizoguchi Y., Ishigaki K., Kojima T., Nagai T.: Birth of piglets derived from in vitro fertilization of pig oocytes matured in vitro. Theriogenology 1993, 39, 1303-1311.

32. Yoshioka $K$.: Development and application of a chemically defined medium for the in vitro production of porcine embryos. J. Reprod. Dev. 2011, 57, 9-16.

33. Yoshioka K., Noguchi M., Suzuki Ch.: Production of piglets from in vitroproduced embryos following non-surgical transfer. Anim. Reprod. Sci. 2012, 131, 23-29.

34. Yoshioka K., Suzuki C., Itoh S., Kikuchi K., Iwamura S., Rodriquez-Martinez H. Production of piglets derived from in vitro-produced blastocysts fertilized and cultured in chemically defined media: effects of theophylline, adenosine and cysteine during in vitro fertilization. Biol. Reprod. 2003, 69, 2092-2099.

35. Yoshioka K., Suzuki C., Tanaka A., Anas I., Iwamura S.: Birth of piglets derived from porcine zygotes cultured in a chemically defined medium. Biol. Reprod. 2002, 66, 112-119.

36. Yuan Y., Spate L. D., Redel B. K., Tian Y., Zhou J., Prather R. S.: Quadrupling efficiency in production of genetically modified pigs through improved oocyte maturation. PNAS 2017, E5796-E5804.

37. Zhang M. Z., Wang X., Yang H., Fogo A. B., Murphy B. J., Kaltenbach R., Cheng P., Zinker B., Harris R. C.: Lysophosphatidic Acid Receptor Antagonism Protects against Diabetic Nephropathy in a Type 2 Diabetic Model. J. Am. Soc. Nephrol. 2015, 28, 3300-3311

Corresponding author: Katarzyna Poniedzialek-Kempny, PhD, Department of Reproductive Biotechnology and Cryopreservation, National Research Institute of Animal Production, 32-083 Balice/Kraków, Poland; e-mail: katarzyna.kempny@izoo.krakow.pl 